\title{
Dampak Letak Buah Pada Pohon dan Perlakuan Benih Terhadap Perkecambahan Benih Kakao (Theobroma cacao L.).
}

\author{
Effects of Position of Cacao (Theobroma cacao L.) on The Trees and Its Seed Treatments to \\ Seed Germination
}

\author{
Ahmad Fauzi, Faisal, dan Muhammad Rafli \\ Jurusan Agroekoteknologi Fakultas Pertanian Universitas Malikussaleh \\ Kecamatan Muara Batu, Lhokseumawe
}

\begin{abstract}
Abstrak
Penelitian ini bertujuan untuk mengetahui pengaruh letak buah pada pohon dan perlakuan pada benih terhadap perkecambahan kakao..Penelitian ini dilaksanakan di Desa Tumpok Teungoh Kecamatan Banda Sakti Kota Lhokseumawepada bulan Agustus sampai dengan September 2016.Penelitian ini menggunakan Rancangan Acak Lengkap (RAL) pola faktorial dengan 3 ulangan. Dua faktor yang diteliti adalah (a) letak buah pada pohon dimana L1 = Letak buah pada batang dan L2 = Letak buah pada cabang. (b) faktor perlakuan pada benih dimana $\mathrm{P} 1=$ Tanpa pembersihan pulpa, $\mathrm{P} 2=$ Pembersihan Pulpa. Adapun parameter yang diamati yaitu potensi tumbuh, daya berkecambah, indeks vigor, kecepatan tumbuh dan keserempakan tumbuh benih kakao.Hasil analisis ragam menunjukkan bahwa perlakuan perbedaan letak buah tidak berpengaruh terhadap pengamatan potensi tumbuh maksimum dan daya berkecambah benih kakao, tetapi berpengaruh terhadap pengamatan indeks vigor, kecepatan tumbuh dan keserempakan tumbuh benih kakao.Perlakuan pembersihan pulpa tidak berpengaruh terhadap pengamatan potensi tumbuh, daya berkecambah, kecepatan tumbuh dan keserempakan tumbuh benih, namun perlakuan pembersihan pulpa berpengaruh terhadap pengamatan indeks vigor benih kakao. Tidak terdapat interaksi antara perlakuan perbedaan letak buah dan perlakuan pembersihan pulpa biji kakao terhadap semua tolok ukur yang diamati
\end{abstract}

Kata kunci: benih kakao, letak buah, pembersihan pulpa

\begin{abstract}
This study aims to determine the effect of the location of fruit on trees and treatment on seeds to germination cocoa. This study was conducted in Tumpok Teungoh Village, Banda Sakti Sub-district, Lhokseumawe City, August to September 2016. This study used Completely Randomized Design with 3 replications. Two factors studied were (a) the location of the fruit on the tree where L1 = The location of the fruit on the stem and L2 = The location of the fruit on the branch. (b) treatment factor in seeds where $\mathrm{P} 1$ = Without pulp clearance, $\mathrm{P} 2$ = Pulp cleansing. The parameters observed were potential growth, germination, vigor index, growth rate and synchronization of cocoa seed growth. The result of variance analysis showed that the fruit difference treatment did not affect the observation of maximum growth potential and cocoa seed germination, but it influenced the observation of vigor index, growth rate and synchronization of cocoa seed growth. Treatment of pulp cleansing did not affect the observation of growth potential, germination, growth rate and synchronization of seed growth, but pulp cleansing treatment had an effect on observation of vigor index of cocoa seed. There was no interaction between fruit difference treatment and treatment of cocoa bean pulp cleansing of all observed parameters.
\end{abstract}

Keywords: adaptation, genotype, soybean, intercropping

\section{Pendahuluan}

Indonesia merupakan negara berkembang yang memiliki sumberdaya alam yang melimpah. Salah satu sub sektor yang memiliki basis sumber daya alam adalah sub sektor perkebunan. Di provinsi Aceh tanaman kakao berkembang dengan pesat pada tahun 1980-an, yang tersebar di daerah Aceh Utara, Pidie, Bireun, Aceh Timur, Aceh Tenggara dan Aceh Barat. Luas areal tanaman kakao dan produksinya setiap tahun cenderung meningkat, terutama dalam lima tahun terakhir. Pada tahun 2008 produksi kakao di Aceh mencapai angka 27.295 ton, sedangkan pada tahun 2012 produksi kakao 
meningkat menjadi 40.664 ton (Statistik Pertanian, 2012).

Akan tetapi mutu biji kakao Aceh yang dihasilkan selama ini masih rendah, hal ini dipengaruhi oleh bebarapa faktor seperti lemahnya pengawasan mutu dan kurangnya penerapan teknologi penanganan pasca panen biji kakao ditingkat masyarakat. Selama ini, kebanyakan petani kakao di Aceh tidak mendahulukan kualitas biji kakao yang akan di tanam, sehingga mutu biji kakao yang dihasilkan relatif rendah, dan harga jualnya juga rendah.

Kakao (Theobroma cacao L) merupakan salah satu komoditas terbesar disektor perkebunan ketiga setelah karet dan kelapa sawit. Kakao merupakan salah satu sumber utama pendapatan petani di 31 provinsi dengan melibatkan sejumlah 1.539.401 kepala keluarga petani (Ditjen Perkebunan, 2011). Komoditi kakao memegang peranan cukup penting dalam perekonomian Nasional, yang khususnya sebagai penyedia lapangan kerja, sumber pendapatan dan devisa negara. Disamping itu kakao juga berperan dalam mendorong pengembangan wilayah dan pengembangan agroindustri.

Produktivitas kakao yang tinggi di Indonesia tidak dibarengi dengan peningkatan kualitas biji kakao. Pada umumnya mutu kakao yang dihasilkan oleh para petani di Indonesia tidak difermantasi, tidak cukup kering, ukuran biji tidak seragam, kadar kulit tinggi, keasaman tinggi, cita rasa sangat beragam dan tidak konsisten. Mutu kakao Indonesia dinilai konsumen pasar Eropa sangat kurang, sehingga ekspor kakao Indonesia selain tidak mendapat premi, juga mengalami penurunan harga yang cukup tinggi (Siswoputranto, 1994). Hal tersebut tentunya menjadi suatu hal yang sangat merugikan bagi Negara kita, terutama petani kakao. Mutu dari biji kakao dipengaruhi oleh berbagai faktor seperti proses budidaya, maupun penanganan pasca panen. Maka dari itu faktor tersebut harus diperbaiki, terutama dalam hal penanganan pasca panen untuk menghasilkan biji kakao yang bermutu, sehingga baik digunakan pada proses pengolahan selanjutnya dalam menghasilkan produk olahan kakao bermutu tinggi. Tanaman kakao termasuk golongan tanaman tahunan yang tergolong dalam kelompok tanaman caulofloris, yaitu tanaman yang berbunga dan berbuah pada batang dan cabang. Dengan mempelajari struktur buah kakao kita dapat mengetahui bagian dari pohon yang memiliki atau menghasilkan kualitas biji kakao berdasarkan posisi buah pada pohon.

Secara teknis, rendahnya produktivitas dan mutu kakao disebabkan beberapa hal diantaranya, benih yang digunakan beragam dan lokal, pemeliharaan dilakukan seadanya dan belum dilakukan fermentasi sebagai faktor penentu kakao.Benih kakao merupakan titik awal dari segala aktivitas pertumbuhan dan perkembangan tanaman kakao. Oleh karena itu, penanganan perbenihan kakao perlu dilakukan secara tepat dan konseptual (Rahardja, 2011).

Benih kakao bermutu, umumnya hanya disediakan oleh perkebunan besar. Perkebunan besar terletak berjauhan dengan perkebunan rakyat, sehingga memerlukan waktu relatif lama selama pengiriman, sehingga dapat menurunkan mutu benih, terutama mutu fisiologis (Adelina dan Maemunah, 2004).

\section{Bahan dan Metode}

Penelitian ini dilaksanakan pada bulan Agustus sampai dengan September 2016.Penelitian ini dilaksanakan di Desa Tumpok Teungoh Kecamatan Banda Sakti Kota Lhokseumawe.

Alat-alat yang digunakan adalah penggaris (mengukur tinggi tanaman), cangkul, nampan, ayakan dan alat tulis menulis. Bahan-bahan yang akan digunakan adalah benih kakao varietas Sulawesi 1, dan pasir.

Penelitian ini menggunakanRancangan Acak Lengkap (RAL) pola faktorial dengan 3 ulangan.

Ada 2(dua) faktor yang diteliti: (1) Faktor letak buah pada pohon yaitu L1 = Letak buah pada batang dan L2 = Letak buah pada cabang. (2) Faktor perlakuan pada benih yaitu $\mathrm{P} 1=$ Tanpa pembersihan pulpa dan $\mathrm{P} 2=$ Pembersihan Pulpa 
Dengan demikian terdapat 4 (empat) kombinasi perlakuan dan setiap kombinasi perlakuan diulang 3 (tiga) kali sehingga diperoleh 12 kombinasi perlakuan.

Model sistematika untuk Rancangan Acak Lengkap (RAL) faktorial adalah sebagai berikut :

$$
\gamma i j k=\mu+L i+P j+(L P) i j+\varepsilon i j k
$$

Keterangan :

Yijk $=$ Hasil pengamatan untuk faktor Letak buah (L) pada taraf ke-i dan faktor perlakuan benih (P) pada taraf ke-j pada tiga ulangan ke-k

$\mu \quad=$ nilai tengah

$\mathrm{Pi}=$ Pengaruh faktor letak buah $(\mathrm{L})$ pada taraf ke-i

$\mathrm{Ki}=$ Pengaruh faktor perlakuan benih $(P)$ pada taraf ke-j
$(\mathrm{PK}) \mathrm{ij}=$ Pengaruh interaksi letak buah (L) pada taraf ke-i dan perlakuan benih $(\mathrm{P})$ pada taraf ke-j

$\Sigma \mathrm{ijk}=$ Galat (pengaruh acak)

Data hasil pengamatan dianalisis secara statistik dengan menggunakan analisis ragam.Jika hasil uji $\mathrm{F}$ menunjukkan adanya pengaruh yang nyata antara perlakuan, maka analisa dilanjutkan dengan uji lanjut BNT pada tarf $5 \%$.

\section{Hasil dan Pembahasan}

\subsection{Tabel Rekapitulasi}

Hasil analisis sidik ragam terhadap pengamatan viabilitas dan vigor benih kakao akibat perlakuan perbedaan letak buah dan pembersihan biji kakao secara lengkap tertera pada tabel rekapitulasi hasil (Tabel 1).

Tabel 1. Tabel Rekapitulasi.

Rekapitulasi hasil analisis ragam potensi tumbuh, daya berkecambah, indeks vigor, kecepatan tumbuh dan keserempakan tumbuh benih akibat perlakuan letak buah dan pembersihan pulpa benih kakao.

\begin{tabular}{lcccc}
\hline \multicolumn{1}{c}{ Pengamatan } & L & P & LXP & KK (\%) \\
\hline Potensi Tumbuh Maksimum & tn & tn & tn & 1,55 \\
Daya Berkecambah & tn & tn & tn & 8,29 \\
Indeks Vigor & $*$ & $*$ & tn & 26,49 \\
Kecepatan Tumbuh & $*$ & tn & th & 19,74 \\
Keserempakan Tumbuh & $*$ & tn & tn & 15,40 \\
\hline
\end{tabular}

Keterangan : L = Letak Buah, $\mathrm{P}=$ Pembersihan Pulpa, $\mathrm{tn}=$ Tidak Berbeda Nyata, $*$ = Berbeda Nyata.

1.2. Rata-rata potensi tumbuh, daya berkecambah, indeks vigor, kecepatan tumbuh dan keserempakan tumbuh benih kakao.

Hasil analisis ragam menunjukkan bahwa perlakuan perbedaan letak buah tidak berpengaruh terhadap pengamatan potensi tumbuh maksimum dan daya berkecambah benih kakao, tetapi berpengaruh terhadap pengamatan indeks vigor, kecepatan tumbuh dan keserempakan tumbuh benih kakao.

Perlakuan pembersihan pulpa tidak berpengaruh terhadap pengamatan potensi tumbuh, daya berkecambah, kecepatan tumbuh dan keserempakan tumbuh benih, namun perlakuan pembersihan pulpa berpengaruh terhadap pengamatan indeks vigor benih kakao.

Tidak terdapat interaksi antara perlakuan perbedaan letak buah dan perlakuan pembersihan pulpa biji kakao terhadap semua pengamatan yang diamati (Lampiran 3, 5, 7, 9, dan 11). Rata-rata potensi tumbuh maksimum, daya berkecambah, indeks vigor, kecepatan dan keserempakan tumbuh benih kakao tertera pada Tabel 1. 
Tabel 2.Rata-rata potensi tumbuh maksimum, daya berkecambah, indeks vigor, kecepatan dan keserempakan tumbuh benih kakao akibat perlakuan perbedaan letak buah dan perlakuan pembersihan pulpa biji kakao.

\begin{tabular}{|c|c|c|c|c|c|}
\hline \multirow{2}{*}{ Perlakuan } & \multicolumn{5}{|c|}{ Pengamatan } \\
\hline & PTM $(\%)$ & $\mathrm{DB}(\%)$ & IV (\%) & Kct $(\%)$ & Kst (\%) \\
\hline \multicolumn{6}{|l|}{ Letak Buah } \\
\hline L1 (buah pada batang) & 98,83 a & 95,83 a & $33,87 \mathrm{a}$ & 57,63 a & $63,55 \mathrm{a}$ \\
\hline L2 (buah pada cabang) & $98,83 \mathrm{a}$ & $88,33 \mathrm{a}$ & $23,95 \mathrm{~b}$ & $42,25 \mathrm{~b}$ & $49,40 \mathrm{~b}$ \\
\hline \multicolumn{6}{|l|}{ Perlakuan Benih } \\
\hline P1 ( Tanpa pembersihan) & 98,83 a & 90,83 a & $23,10 \mathrm{~b}$ & $43,74 \mathrm{a}$ & $50,96 \mathrm{a}$ \\
\hline P2 (Pembersihan pulpa) & $98,83 \mathrm{a}$ & $93,33 \mathrm{a}$ & $34,73 \mathrm{a}$ & $56,14 \mathrm{a}$ & $61,99 \mathrm{a}$ \\
\hline
\end{tabular}

Tabel 2 menunjukkan bahwa perlakuan perbedaan letak buah pada batang dan cabang dan pembersihan biji kakao tidak mempengaruhi potensi tumbuh maksimum benih kakao. Potensi tumbuh akibat perlakuan letak buah dan pembersihan buah sama-sama memiliki nilai persentase potensi tumbuh yang besar yaitu $98,33 \%$. Secara stastistik perbedaan letak buah dan perlakuan pembersihan pulpa pada benih kakao tidak mempengaruhi daya berkecambah benih kakao, namun jika dilihat secara rata-rata perlakuan perbedaan letak buah dan perlakuan pembersihan pulpa mempengaruhi daya berkecambah benih kakao.

Letak buah pada batang memiliki persentase daya berkecambah sebesar 95,00 $\%$ dibandingkan dengan letak buah pada cabang yang persentase daya berkecambah berkisar 88,33 \%. Perlakuan pembersihan pulpa dapat meningkatkan persentase daya berkecambah sebesar 93,33 \% dibandingkan dengan perlakuan tanpa pembersihan pulpa diperoleh persentase daya berkecambah sebesar $90,83 \%$ Pada pengamtan indeks vigor perlakuan perbedaan letak buah dan perlakuan pembersihan buah mempengaruhi indeks vigor dan kecepatan tumbuh benih kakao. Persentase indeks vigor benih sebesar 33,33 \% terdapat pada perlakuan letak buah pada batang. Pada perlakuan pembersihan pulpa persentase indeks vigor benih kakao yang didapatkan yaitu 33,33 \% . Letak buah pada batang menghasilkan persentase kecepatan tumbuh sebesar $57,63 \%$ dibandingkan dengan letak buah pada cabang hanya memiliki persentase kecepatan tumbuh sebesar 42,25 \%. Pada perlakuan pembersihan pulpa menghasilkan persentase kecepatan tumbuh yang besar yaitu 56,14 \% dibandingkan dengan perlakuan tanpa pembersihan pulpa persentase kecepatan tumbuh benih kakao yaitu $43,74 \%$.

Keserempakan tumbuh benih kakao juga dipengaruhi oleh perbedaan letak buah. Letak buah pada batang menghasilkan persentase keserempakan tumbuh sebesar $79,17 \%$ dibandingkan dengan letak buah pada cabang hanya memiliki persentase keserempakan tumbuh sebesar 57,50 \%. Pada perlakuan pembersihan pulpa menghasilkan persentase keserempakan tumbuh yang besar yaitu 76,67 \% dibandingkan dengan perlakuan tanpa pembersihan pulpa persentase keserempakan tumbuh benih kakao yaitu 60,00 \% .

Berdasarkan penjelasan diatas didapatkan bahwa letak buah pada batang dan perlakuan permbersihan pulpa merupakan perlakuan terbaik terhadap viabilitas dan vigor benih kakao.Hal ini 
dikarena letak buah pada batang memiliki perbedaan dengan letak buah pada cabang.

Berbedanya posisi buah pada pohon mempengaruhi karakteristik fisik, kadar air dan komposisi kimia pada buah kakao. Ukuran biji kakao berdasarkan posisi buah pada batang dan posisi buah pada cabang berbeda ukurannya, Hal ini disebabkan karena persaingan untuk memperoleh makanan pada cabang lebih besar dibandingkan persaingan untuk memperoleh makanan pada batang (Hasbawati, 2006).

Perbedaan ukuran biji pada buah yang terletak pada batang mempengaruhi perkecambahan benih.Benih yang ukuran besar memiliki cadangan makanan yang banyak dibandingkan dengan ukuran biji yang kecil.

Pada umumnya jumlah buah pada cabang lebih banyak dibandingkan dengan batang.Hal ini disebabkan karena banyaknya tangkai pada cabang yang ditumbuhi oleh buah dibandingkan pada batang.Akan tetapi, ukuran buah pada batang lebih besar dan lebih berat dibandingkan buah yang berada pada cabang.

Pengaruh pengupasan pulpa dan kulit ari pada benih kakao memberikan pengaruh yang nyata. Pengupasan pulpa dilakukan untuk mempercepat proses imbibisi pada benih. Kandungan air yang tinggi dalam biji dapat menghambat proses perkecambahan, karena air dibutuhkan dalam proses perkecambahan, akan tetapi apabila kelebihan air juga dapat mengganggu proses pertukaran $\mathrm{O}_{2}$ pada benih.

Imbibisi merupakan proses masuknya air karena adanya perbedaan konsentrasi, yaitu dari konsentrasi tinggi ke konsentrasi rendah. Imbibisi pada tumbuhan umumnya terjadi pada proses penyerapan unsur-unsur yang dibutuhkan oleh tumbuhan khususnya air. Bersamaan dengan prosesimbibisi akan terjadi peningkatan laju respirasi yang akan mengaktifkan enzim-enzim yang terdapat di dalamnya sehingga terjadi proses perombakan cadangan makanan (katabolisme) yang akan menghasilkan energi dan unsur hara yang diikuti oleh pembentukan protein untuk pembentukan sel-sel baru pada embrio.

Kedua proses ini terjadi secara berurutan dan pada tempat yang berbeda. Akibat terjadinya proses imbibisi kulit benih akan menjadi lunak dan retak-retak. Pembentukan sel-sel baru pada embrio akan diikuti proses diferensiasi sel-sel sehingga terbentuk plumula yang merupakan bakal batang dan daun serta radikula yang merupakan bakal akar. Kedua bagian ini akan bertambah besar sehingga akhirnya benih akan berkecambah (Kuswanto, 1996).

Berdasarkan hasil penelitian diketahui bahwa pengupasan pulp dan kulit ari memberikan pengaruh yang nyata terhadap parameter pengamatan tinggi dan jumlah daun bibit kakao, namun tidak berpengarun nyata terhadap parameter diameter batang, berat basah serta luas daun bibit kakao.

Hal ini disebabkan karena dengan pengupasan pulp dan kulit ari membantu mempercepat pertumbuhan bibit kakao. Tinggi bibit kakao berpengaruh nyata mulai umur 6 MSPT, dimana bibit kakao tertinggi yaitu secara berturut ditunjukkan pada perlakuan pengupasan pulp benih kakao dengan direndam dengan air kapur terlebih dahulu kemudian pengupasan pulp dengan dicampur abu gosok dan pengupasan kulit ari (Alridiwirsah et al., 2011).

(Alridiwirsah, et al. 2011) dari hasil penelitiannya tentang perlakuan penghilangan pulp (ekstraksi) terdiri dari pencucian dengan air, pencucian dengan larutan kapur 2,5\%, digosok dengan abu, digosok dengan tanah, digosok dengan pasir dan mengelupas kulit ari menunjukkan bahwa perlakuan ekstraksi dengan terlebih dahulu merendam dengan air kapur adalah perlakuan ekstraksi terbaik karena memberikan pengaruh terbaik pada perkecambahan benih kakao (ditunjukkan dengan peubah daya tumbuh dan kecepatan tumbuh) dan pertumbuhan bibit kakao (ditunjukkan oleh peubah tinggi bibit dan panjang akar) 


\section{Simpulan}

Berdasarkan hasil penelitian yang telah dilakukan, maka dapat disimpulkan sebagai berikut:

1. Perbedaan letak buah tidak berpengaruh terhadap pengamatan potensi tumbuh maksimum dan daya berkecambah benih kakao, tetapi berpengaruh terhadap pengamatan indeks vigor, kecepatan tumbuh dan keserempakan tumbuh benih kakao.

2. Pembersihan pulpa tidak berpengaruh terhadap pengamatan potensi tumbuh, daya berkecambah, kecepatan tumbuh dan keserempakan tumbuh benih, namun perlakuan pembersihan pulpa berpengaruh terhadap pengamatan indeks vigor benih kakao.

3. Tidak terdapat interaksi antara perlakuan perbedaan letak buah dan perlakuan pembersihan pulpa biji kakao terhadap semua tolok ukur yang diamati

\section{Daftar Pustaka}

Adelina, E., dan Maemunah, 2004. Pemotongan dan Pemberian Sitokinin pada Akar Kecambah Kakao. J. AgrolandVol. 11 No. 3 : 255-260

Alridiwirsah, Asritanarni dan Fitri Anggun Sari. 2011. Perlakuan Benih Dan Pemupukan Terhadap Pertumbuhan Bibit Kakao (Theobroma cacao L.) TSH8.(Online)jurnal.umsu.ac.id/index. php/agrium/article/view/258 Diakses pada 18 Desember 2015.

Ashari, S. 2006. Budidaya Dengan Pemupukan Yang Efektif dan Pengoptimalan Peran Bintil Akar Kedelai. Penebar Swadaya. Bogor.

BPS. 2012. Aceh dalam Angka. (online) http://regionalinvestment.bkpm.go.id/
Di akses pada tanggal 22 November 2015.

Ditjenbun.2006. Statistik Perkebunan Indonesia 2004-2006, Kakao (Cocoa). Jakarta.

Direktorat Jenderal Perkebunan. 2011. Statistik Perkebunan Indonesia 200420011, Kakao (Cocoa).Jakarta.

Bewley, J.D. (1997). Seed germination anddormancy. The Plant Cell, 9, 10551066.

Haerani, 2002. Pola Distribusi Kadar Lemak, Kadar Air dan Karakteristik Fisik Biji Kakao Forastero (Theobroma cacao) Berdasarkan Barisan Biji Dari Pangkal Buah Ke Ujung Buah. Fakultas Pertanian dan Kehutanan Universitas Hasanuddin. Makassar.

Hasbawati, 2006. Karakteristik Fisik Biji Buah Kakao Menurut Posisinya Pada Pohon. Fakultas Pertanian dan Kehutanan Universitas Hasanuddin. Makassar.

Jurniati. 2013. Pola Sebaran Karakteristik Fisik Biji Kakao (Theobroma cacao L.) Berdasarkan Posisi Buah Pada Pohon. [Skripsi].

Khan, A. A. 1992. Preplant Phyisiological Seed Conditioning.P : 131-181. In J.Janick ed. Hort. Rev. Wiley and Sons, inc., New York.

Karmawati, E., Z. Mahmud, M. Syakir, J. Munarso, K. Ardana dan Rubiyo. 2010. Budidaya dan Pasca Panen Kakao. Pusat Penelitian dan Pengembangan Perkebunan.92 hal.

PrawotoA.A dan IskandarAbdul Karneni, 1994.PengaruhTinggiTempatPenanam anKakaoTerhadap Kadar LemakdanKomposisiAsamLemak.Pusat Penelitian Kopi dankakao.Jember. Indonesia.

Rahardja, P. 2011. Menghasilkan Benih dan Bibit Kakao Unggul. Penebar Swadaya. Jakarta. 
Rahardja, P., 1999. Perkembangan bahan tanam kakao di Indonesia. Warta Pusat Penelitian Kopi dan Kakao, 15(2): 184-189.

Rahmat.2010. Mutu Fisik Biji Buah Kakao BerdasarkanLetakKetinggianTumbuh Di Atas Permukaan Laut. Online: skripsiamet.blogspot.com/Diakses 18 Desember 2015. [Skripsi].

Saleh, M.S., 1994. Deteriorasi Biokimiawi dan Benih Kakao Berkecambah Selama Penyimpanan. J. Agroland, Vol 2 (6):1-5

Siregar, Tumpal H.S, Slamet Riyadi., Laeli Nuraeni. 2012. Budi Daya Cokelat. Penebar Swadaya. Jakarta

S.P., Aji Kristanto. 2015. Panduan Budidaya Kakao. Pustaka Baru Press.Yogyakarta.

Sutopo, L. (2002). Teknologi Benih. RajaGrafindo Persada, Jakarta.

Siswoputranto, P. S., 1983). Budidaya dan Pengolahan Coklat.Balai Penelitian Bogor, Sub Balai Penelitian Budidaya, Jember.

Wahyudi, T., T.R Panggabean, dan Pujianto.2008. Panduan Lengkap Kakao Manajemen Agribisnis dan Hulu Hingga Hilir. Penebar Swadaya. Jakarta. 